haematological reactions to allopurinol have been reported after months or years of medication. ${ }^{1}$ Granulomatous reactions are also a known hypersensitivity response to insoluble antigen and may occur without any other associated signs of allergy. ${ }^{10}$ Furthermore, this case provides direct evidence for an allopurinol-associated granulomatous reaction: after being re-exposed to the drug the patient showed a prompt exacerbation of his previous symptoms and abnormal liver function values. The reappearance of a dose-independent drug reaction when medication is resumed after a drug-free interval is consistent with a "definitive" adverse allergic reaction to that drug. ${ }^{911}$

Unfortunately, no serological evidence to prove an allergic mechanism is available. Circulating drug antibodies empirically associated with hepatic injury have not been shown. Furthermore, the significance of anti-liver and antimitochondrial antibodies in patients with drug-induced liver disease is uncertain and their relevance to an allergic mechanism is unclear. Serological study of our patient's serum was not undertaken.

The initial histological examination of the patient's liver biopsy specimen in March 1977 showed many granulomas in portal tracts and in all zones of the liver acinus. When the drug was permanently discontinued the clinical and biochemical abnormalities resolved within three weeks. The patient felt better, and when examined six months later had normal laboratory values and no granulomas in the liver. The granulomas probably disappeared much sooner, as suggested in cases of granulomatous hepatitis associated with sulphadimethoxine, ${ }^{7}$ phenylbutazone, ${ }^{8}$ and allopurinol. ${ }^{4}$

It is possible that we obtained an unrepresentative section of liver on needle biopsy, thereby missing an area of granuloma. But the sample contained nine portal tracts, and, compared with the diffuse distribution of the granulomas in the wedge biopsy, it is extremely unlikely that a sampling error could have accounted for the absence of granulomas.

It is not surprising that serum transaminase and alkaline phosphatase concentrations were mildly raised and that the bilirubin concentration was normal, even in the presence of numerous granulomas, as liver parenchyma adjacent to and remote from these areas appeared normal. The absence of histopathological evidence of hepatitis may also have accounted for the latent period (three weeks) between readministration of the drug and onset of symptoms.

The absence of respiratory symptoms and lymphocytosis and the presence of granulomas characterised by multinucleated giant cells and eosinophils differentiates our case from that reported by Eliakim et al, ${ }^{12}$ who described a granulomatous hepatitis accompanying a selflimited febrile disease. Our case resembles in part that reported by Simmons et al. ${ }^{4}$ Their patient developed an acute granulomatous hepatitis after one month's treatment with allopurinol which resolved two weeks after the drug was discontinued. In our patient, however, symptoms of an adverse drug reaction became apparent after six years of allopurinol medication and improved over-three weeks. Direct evidence for an allergic drug reaction was also available, since our patient was inadvertently rechallenged with allopurinol, which resulted in a recurrence of fever, malaise, and gastrointestinal distress. Unlike the case reported by Simmons et $a l,{ }^{4}$ the granulomas were not associated with hepatitis.

In view of the increasing number of reports of granulomas associated with drug treatment, the clinician should take a careful drug history in such patients and consider drug reaction in the differential diagnosis after excluding infectious and multisystem diseases. Although the evidence is not conclusive, a causal association seems to exist between allopurinol and hepatic granulomas.

We thank Drs R Ritchie, N Ellison, $\mathrm{H}$ Linton, and $\mathrm{N}$ Fremes for allowing us to report this case, Stan Shockey for his photographic help, and Mrs Evelyn Millar for preparation of the manuscript.

1 Woodbury, D M, and Fingle, E, in Pharmacological Basis of Therapeutics, ed L Goodman and A Gilman. New York and London, Macmillan, 1975.

${ }^{2}$ Butler, R C, et al, fournal of the American Medical Association, 1973, 237, 473.

${ }^{3}$ Mills, R M, jun, fournal of the American Medical Association, 1973, 216, 799.

4 Simmons, F, Feldman, B, and Gerety, D, Gastroenterology, 1972, 62, 101.

5 Rappaport, A M, Microvascular Research, 1973, 6, 212.

6 Guckian, J C, and Perry, J E, Annals of Internal Medicine, 1966, 65, 1081.

${ }^{7}$ Esperitu, C R, Kim, T S, and Levine, R A, Fournal of the American Medical Association, 1967, 202, 985.

${ }^{8}$ Goldstein, G, Annals of Internal Medicine, 1963, 59, 97.

- Zimmerman, H J, in International Encyclopaedia of Pharmacology and Therapeutics, ed M Samter, Section 75, p 299. New York, Pergamon Press, 1972.
10 Sell, S, in Pathology, ed W Anderson and J Kissane. St Louis, Mo, C V Mosby, 1972.

11 Karsh, F E, and Lasagna, L, fournal of the American Medical Association, $1975,234,1236$.

12 Eliakim, M, et al, Lancet, 1968, 1, 1348.

(Accepted 31 March 1978)

Department of Pathology, Toronto Western Hospital, Toronto, Canada M5T 2S8

A MEDLINE, MD, FRCP(C), consultant pathologist

L B COHEN, MSC, research scientist

Department of Medicine, North York Branson Hospital, Toronto, Canada

B A TOBE, MD, FRCP(C), consultant physician

Division of Clinical Pharmacology, Toronto Western Hospital, Toronto, Canada

E M SELLERS, MD, FRCP(c), consultant physician

\section{Prevalence of latent perhexiline neuropathy}

Since the introduction of perhexiline therapy in angina pectoris, clinical evidence of toxic polyneuropathy has been reported for about one case per 1000 treated patients. Ganglioside storage ${ }^{1}$ and cytoplasmic inclusion ${ }^{2}$ in the Schwann cells have been described in such cases. Slowing of both sensory and motor conduction velocities (SCV and $\mathrm{MCV}$ ) of various peripheral nerves has been observed in all reported cases. ${ }^{3}$

We performed an investigation to discover the prevalence of latent neuropathy in patients on perhexiline and to determine how useful various electrophysiological procedures were for detecting subclinical nerve disease.

\section{Patients, methods, and results}

Thirty-five patients who were receiving perhexiline were studied: none had clinical evidence of neuropathy or any other disease affecting the nerves. Three electrophysiological values were recorded: $(a)$ cutaneous SCV of ulnar nerve, $(b) \mathrm{MCV}$ of ulnar and popliteal nerves, and $(c)$ the $\mathrm{H}$ reflex of the soleus muscle. The results were compared with those of a control group of normal subjects of corresponding ages (group 2). All recordings were performed at the same temperature, with current electromyographical techniques.

Mean electrophysiological values $( \pm S D)$ in patients (group 1) and controls (group 2). Percentages of patients with abnormal values (control mean $\pm 2 S D$ ) are also shown

\begin{tabular}{|c|c|c|c|c|}
\hline & $\begin{array}{l}\text { Group 1 } \\
(n=36)\end{array}$ & $\begin{array}{l}\% \text { of } \\
\text { patients } \\
\text { with } \\
\text { abnormal } \\
\text { values }\end{array}$ & $\underset{(n=15)}{\text { Group 2 }}$ & $P$ value \\
\hline $\begin{array}{l}\text { Tibial nerve (soleus } \mathrm{H} \text { reflex): } \\
\begin{array}{c}\text { Latency response }(\mathrm{ms}) \\
\text { Latency of } \mathrm{H} \text { reflex }(\mathrm{ms}) \\
\mathrm{H} \text { max: } M \text { max amplitude }\end{array}\end{array}$ & $\begin{array}{r}5 \cdot 6 \pm 1 \cdot 0 \\
33 \cdot 1 \pm 3 \cdot 4\end{array}$ & 37 & $\begin{array}{r}5 \cdot 0 \pm 0 \cdot 5 \\
30 \cdot 5 \pm 0 \cdot 4\end{array}$ & $\begin{array}{l}\text { NS } \\
0.01\end{array}$ \\
\hline 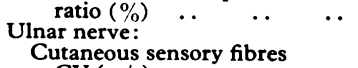 & $22 \cdot 4 \pm 15 \cdot 9$ & 65 & $45 \cdot 2 \pm 11 \cdot 7$ & 0.001 \\
\hline $\begin{array}{l}\text { CV (m/s) } \\
\text { Motor fibres distal latency (ms) } \\
\text { Motor fibres, forearm CV }(\mathrm{m} / \mathrm{s})\end{array}$ & $\left|\begin{array}{r}50 \cdot 4 \pm 6 \cdot 1 \\
3 \cdot 4 \pm 0 \cdot 6 \\
53 \cdot 9 \pm 6 \cdot 7\end{array}\right|$ & 24 & $\begin{array}{r}51 \cdot 5 \pm 3 \cdot 9 \\
3 \cdot 1 \pm 0 \cdot 3 \\
52 \cdot 2 \pm 5 \cdot 7\end{array}$ & $\begin{array}{l}\text { NS } \\
0.05 \\
\text { NS }\end{array}$ \\
\hline $\begin{array}{l}\text { Popliteal nerve: } \\
\text { Motor fibres distal latency (ms) } \\
\text { Motor fibres, leg CV }(\mathrm{m} / \mathrm{s}) \quad \ldots\end{array}$ & $\begin{array}{r}5 \cdot 3 \pm 0 \cdot 8 \\
49 \cdot 6 \pm 8 \cdot 1\end{array}$ & 30 & $\begin{array}{r}4 \cdot 8 \pm 0 \cdot 7 \\
48 \cdot 5 \pm 4 \cdot 1\end{array}$ & $\begin{array}{l}0.05 \\
\text { NS }\end{array}$ \\
\hline
\end{tabular}

The results are shown in the table. The $\mathrm{H}$ reflex was disturbed in patients in group 1: $65 \%$ had a decrease of $\mathrm{H}$ max: $M$ max amplitude ratio and $37 \%$ an increase in latency of the $\mathrm{H}$ reflex. Distal motor latencies were increased in both ulnar $(24 \%)$ and popliteal $(30 \%)$ nerves. No abnormality was found in the cutaneous SCV of ulnar nerve. No correlation between electrophysiological findings and the dose of perhexiline or length of treatment was observed. 


\section{Comment}

As shown by the $H$ max:M max amplitude ratio study, latent neuropathy seems to be common in patients receiving perhexiline, affecting two-thirds of the treated population. This study also shows that the $\mathrm{H}$ reflex latency and the distal motor latencies are useful indices for detecting subclinical nerve disease and for estimating its severity.

${ }^{1}$ Pollet, S, et al, Lancet, 1977, 1, 411.

2 Mussini, J M, Hauw, J J, and Escourolle, R, Acta Neuropathologica, 1977, $38,53$.

${ }^{3}$ Bousser, M G, et al, Annales de Cardiologie, 1977, 26, 493.

(Accepted 20 March 1978)

Faculté de Medecine Saint-Antoine, Laboratoire de Physiologie, 75571 Paris Cedex 12

ALAIN SEBILLE, MD, physician

\section{Interstitial nephritis in a case of phenylbutazone hypersensitivity}

Phenylbutazone is a commonly used drug, and gastrointestinal and haematological side effects and sodium retention are well documented. Acute renal failure, and particularly interstitial nephritis, is a less well known effect and only a few cases have been recorded. We report here a case of acute interstitial nephritis associated with fever, rash, hepatitis, and eosinophilia after phenylbutazone ingestion.

\section{Case report}

A 48-year-old housewife received phenylbutazone $200 \mathrm{mg}$ three times a day for a painful right elbow. Two days after the end of a three-week course she developed fever, rigors, lymphadenopathy, and a diffuse, erythematous, purpuric rash. On admission to hospital the rash was still florid, blood pressure was $120 / 85 \mathrm{~mm} \mathrm{Hg}$, and there was mild hepatomegaly. Investigations showed: haemoglobin $13.9 \mathrm{~g} / \mathrm{dl}$; platelets $80 \times 10^{9} / 1$; total WBC $19 \cdot 4 \times 10^{9} / 1$ with a $36 \%$ eosinophilia. Blood urea concentration was initially $14.3 \mathrm{mmol} / 1(86 \mathrm{mg} / 100 \mathrm{ml})$ but fell to $4.5 \mathrm{mmol} / 1(27 \mathrm{mg} / 100 \mathrm{ml})$ after intravenous fluid replacement. Serum creatinine was $118 \mu \mathrm{mol} / 1(1.3 \mathrm{mg} /$ $100 \mathrm{ml}) ; \gamma$-glutamyltranspeptidase $140 \mathrm{IU} / 1$; serum aspartate aminotransferase $312 \mathrm{IU} / \mathrm{l}$; alkaline phosphatase $607 \mathrm{IU} / \mathrm{l}$; bilirubin $17 \mu \mathrm{mol} / 1(1 \mathrm{mg} /$ $100 \mathrm{ml}$ ). Urine microscopy showed leucocytes, epithelial cells, and granular casts with no appreciable proteinuria. Bone marrow aspiration showed hyperactivity only. Skin biopsy showed dilatation of dermal capillaries and perivascular infiltration by lymphocytes together with some nuclear fragments. There was also focal extravasation of red cells and a picture compatible with an allergic drug reaction. She was negative for autoimmune antibodies, DNA antibody binding was $28 \mathrm{U} / \mathrm{ml}$ (Amersham radioimmune assay $0-25 \mathrm{U} / \mathrm{ml}$ ); C3 $1040 \mathrm{mg} / 1$ (normal $700-1800 \mathrm{mg} / \mathrm{l}$ ); C4 $350 \mathrm{mg} / \mathrm{l}$ (normal $140-700 \mathrm{mg} / \mathrm{l})$; and there was no anticomplementary activity. IgG was $19.5 \mathrm{~g} / 1$ (normal $5-18 \mathrm{~g} / \mathrm{l}$ ), IgM $2.4 \mathrm{~g} / 1$ (normal $0.5-2.5 \mathrm{~g} / \mathrm{l}$ ), IgA $10.5 \mathrm{~g} / 1$ (normal $0 \cdot 5-2.5 \mathrm{~g} / \mathrm{l}$ ); total IgE by the Prist method $8540 \mathrm{U} / \mathrm{ml}$ (mean +2 SD $=122 \mathrm{U} / \mathrm{ml}+275 \mu \mathrm{g} / \mathrm{l}$ )

The rash faded, but on the 16th day of her illness she developed further pyrexia and associated loin tenderness. Midstream urine examination showed a significant growth of Streptococcus faecalis, and amoxycillin was started. Despite this proteinuria increased and red cells appeared in the urine and over the next two days she became anuric. Blood urea concentration was $15.7 \mathrm{mmol} / 1(95 \mathrm{mg} / 100 \mathrm{ml})$ and serum creatinine $530 \mu \mathrm{mol} / \mathrm{l}$ $(6 \mathrm{mg} / 100 \mathrm{ml})$. Peritoneal dialysis was started on day 23 when blood urea concentration was $30.1 \mathrm{mmol} / 1(181 \mathrm{mg} / 100 \mathrm{ml})$ and serum creatinine $1003 \mu \mathrm{mol} / 1(11.3 \mathrm{mg} / 100 \mathrm{ml})$, and this was followed by haemodialysis. Abdominal radiographs showed two $15-\mathrm{cm}$ kidneys, and a renal biopsy performed on day 26 showed considerable interstitial inflammatory infiltrate of plasma cells with occasional polymorphonuclear cells. There was a diffuse interstitial fibrosis with dilatation and localised loss of tubules. Glomeruli showed no hypercellularity or basement membrane abnormality (see figure).
Immunofluorescence studies showed no localisation of immunoglobulins of components of complement within the tubular basement membrane or walls of the vessels. Haemodialysis was discontinued on day 46 , when effective urine volumes had been achieved. Two months later her urea concentration was $12.5 \mathrm{mmol} / 1(75 \mathrm{mg} / 100 \mathrm{ml})$, creatinine $174 \mu \mathrm{mol} / 1(1.9 \mathrm{mg} / 100 \mathrm{ml})$, and $\mathrm{IgE} 1137 \mathrm{U} / \mathrm{ml}$.

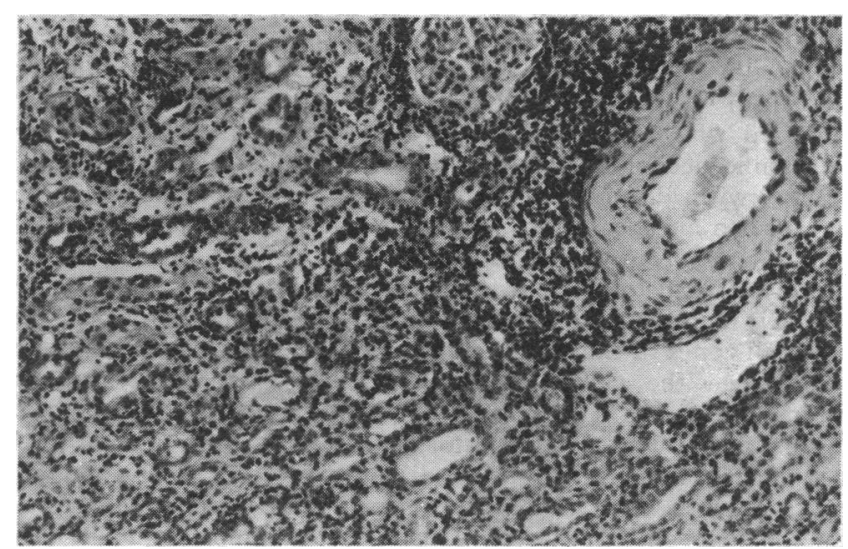

Intense interstitial infiltration and areas of tubular necrosis. ( $\mathrm{H}$ and $\mathrm{E}$. $\times 50$.)

\section{Comment}

The episode of acute interstitial nephritis was thought to be a hypersensitivity reaction to phenylbutazone. This is in keeping with the additional manifestations of hypersensitivity found in this patient, such as fever, eosinophilia, rash, and abnormal liver function values. At the time of developing these abnormalities she was receiving no other medication. Acute interstitial nephritis has been described before, ${ }^{1}$ mainly with methicillin and phenindione. ${ }^{2}$ One report reviews a few cases associated with phenylbutazone, ${ }^{3}$ although these were mainly cases of acute renal failure without the additional features seen in our patient. This syndrome has been reported with ampicillin, and our patient did have amoxycillin, but the drug was given for only two days 16 days after the development of her illness and after the clinical and urinary evidence of renal disease was apparent.

The hypersensitivity reaction in the kidney in this condition is said to be directed against the tubules and there are reports of anti-tubular basement membrane antibodies and linear deposition of $\mathrm{IgG}$ along the tubular basement membrane. ${ }^{4}$ We were unable to show this in our patient. We were, however, able to confirm that measurement of IgE helps to differentiate between acute interstitial nephritis and other causes of acute renal failure. ${ }^{5}$ We would suggest, in view of the other features of hypersensitivity and in the absence of any other causal agent, that this case of acute interstitial nephritis was caused by phenylbutazone treatment.

${ }^{1}$ Mery, J-P, and Morel-Maroger, L, Proceedings of the 6th International Congress of Nephrology, p 524. Basle, Karger, 1976.

${ }^{2}$ McMenamin, R A, Davies, L M, and Craswell, P W, Australian and New Zealand fournal of Medicine, 1976, 6, 583.

3 Fillastre, J P, et al, Actualités Néphrologiques de l'Hôpital Necker, p 155. Paris, Flammarian, 1969.

${ }^{4}$ Border, W A, et al, New England fournal of Medicine, 1974, 291, 381.

5 Ooi, B S, et al, Lancet, 1974, 1, 1254.

(Accepted 29 March 1978)

\section{Leicester General Hospital, Leicester LE5 4PW}

G I RUSSELL, MB, CHB, medical registrar

R F BING, MB, MRCP, lecturer in medicine

J WALLS, MB, MRCP, consultant nephrologist

N M PETTIGREW, FRCs, MRCPATH, senior lecturer in pathology 